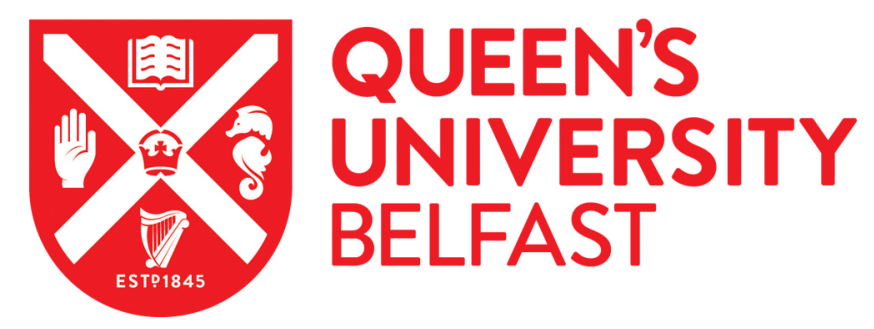

\title{
Far Right Populism and Women: The Normalisation of Gendered Anti- Muslim Racism and Gendered Culturalism in the Netherlands
}

Vieten, U. M. (2016). Far Right Populism and Women: The Normalisation of Gendered Anti-Muslim Racism and Gendered Culturalism in the Netherlands. Journal of Intercultural Studies, 37(6), 621-636.

https://doi.org/10.1080/07256868.2016.1235024

Published in:

Journal of Intercultural Studies

Document Version:

Peer reviewed version

Queen's University Belfast - Research Portal:

Link to publication record in Queen's University Belfast Research Portal

\section{Publisher rights}

(c) 2016 (C) 2016 Informa UK Limited, trading as Taylor \& Francis Group.

This is an Accepted Manuscript of an article published by Taylor \& Francis in Journal of Intercultural Studies on 28th Oct 2016, available online: http://www.tandfonline.com/10.1080/07256868.2016.1235024

\section{General rights}

Copyright for the publications made accessible via the Queen's University Belfast Research Portal is retained by the author(s) and / or other copyright owners and it is a condition of accessing these publications that users recognise and abide by the legal requirements associated with these rights.

Take down policy

The Research Portal is Queen's institutional repository that provides access to Queen's research output. Every effort has been made to ensure that content in the Research Portal does not infringe any person's rights, or applicable UK laws. If you discover content in the Research Portal that you believe breaches copyright or violates any law, please contact openaccess@qub.ac.uk. 


\title{
Far right populism and women: the normalisation of gendered anti- Muslim racism and gendered culturalism in the Netherlands
}

\author{
Ulrike M Vieten, Queen's University Belfast
}

Abstract

The paper approaches the rise of far right populism in Europe with a feminist lens and on the background of the discursively constructed sexist and racist features of the current moral panic debate. It is argued that we can follow up a continuum of normalised culturalist gendered discourses in Europe, and in the Netherlands in particular, for some time. The paper is organised by looking, first, at the place of gender in far right discourses and the role of women in far right wing populist parties. Second, a feminist critique of processes of normalisation is presented helping to clarify the term 'culturalism'. To illustrate the dynamics of gendered culturalism and the way it impacts the everyday life of Muslim women in the Netherlands, some interview sequences of an empirical study (2012) with female Dutch-Moroccan citizens are discussed. The experiences of the women illustrate how far right populist perspectives and prejudices entered their daily lives, and which counter strategies, the women used to resist intimidations. The paper concludes that foremost the Dutch far right and the PVV party leader, Geert Wilders, were successful in normalising gendered culturalist views about Muslim minority women vis-a-vis a 'pseudo-emancipatory' nativist claim of cultural superiority with respect to majority women (and men) in liberal European societies.

Key words: far right populism, Moroccan-Dutch female citizens, 'nativism', gender and sexuality, culturalism, normalization, Anti-Muslim racism. 
'Right-wing populists and extremists are positively celebrating what happened in Cologne as confirmation of their long-held beliefs about foreigners and their allies with the "lying press." Whether PI-News (PI stands for "Politically Incorrect") or Pegida, whether AfD or the neoNazi party NPD, whether the right-wing party ProNRW or the newly converted far-right snobs: All of those who wrote about Cologne revealed in the incident."Templer" wrote in PINews: "The crazy chancellor has allowed millions of male, sexually starved, asocial illegals from the Middle East and Africa to come to Germany. Blond German women are, according to the Koran, 'prey-women' who can be abused according to your whims or enslaved."i

\section{Introduction}

In 2014, Lum and Renaudiere argued that Muslims were stigmatized 'for being violent and for not integrating, but also, for not practicing gender equality and tolerating homosexuality' and 'in far right discourse, gender equality is assumed for have already been conquered in "civilized" Europe'.

The New Year's 2015/2016 large scale sexual attacks on non-migrant women in German public spaces near the main train stations in Cologne and Hamburg, but also in Zurich, Switzerland, for example, drive current far right populist debates on the 'integration and gender equality skills' of new immigrants, and North African male refugees iii, in particular. The link between gender and sexuality is crucial here, too, as in a hegemonic perspective liberal Western and secular Christian societies are identified with female sexual independence, e.g. the domestic and public boundary with respect to the preference and performance of sexuality, and further, freely moving in public spaces is regarded as a fundamental individual human and civic right, equally for men and women. However, public debates on 'sexuality' often get equated with non-heterosexuality that means identified with homosexuality: the public display of sexual preferences (Piekut et. al. 2013) has become both, a signifier of 'progressive individual Western life style' and therefore, a token of liberal society, as well as a racialised boundary marker to 'non-secular' religious minority groups (Vieten 2011; 2012). Heterosexuality and heteronormativity shape public discourse (Valentine 1993; Cooper 2004; Vieten 2014) despite more recent interventions by queer studies scholars (Lugones 2007; Kulpa and Silva 2016) 
little has changed in the national imaginary of a normative common sense of what counts as hegemonic heterosexual and normal sexual identity. Queer scholars such as Puar (2007) argue that gay rights have become a boundary technology to depict the Otherness of Muslims. According to Yilmaz (2015: 38) 'The dichotomous constellation of cultures with gender and sexuality as baselines is symptomatic of the way sociopolitical divisions are imagined, and acted upon, in public discourse.' The '(hetero-)sexual' sexing of a national group boundary highlighted here is relevant to the current 'moral panic' rhetoric and the rise of far right populist parties: the topic of sexual violence against 'native' women in the public space signifies the liberal society's outrage. Unlike domestic sexual violence it conveys ideologically loaded messages also referring to a symbolic 'imagined' boundary between as 'native' addressed women (victims) and the 'non-native' Other men (perpetrators).

On the background of an essentialist binary between 'woman' ascribed as belonging to the dominant collective, and the 'foreign' man, the question occurs what the situation, and agency of the ascribed 'non-native' woman in the public domain might be? Is she assigned to the domestic sphere, and does not have a public voice and role to play in the public and political imagination of the majority collective? In what ways are female Muslim minority citizens affected by gendered anti-Muslim racism and the normalization of far right policy discourses and politics?

In this paper, I will link some of the discursively constructed sexist and racist features of the current moral panic debate with the rise of far right populism underscoring a continuum of normalising culturalist gendered discourses in Europe.

To illustrate these processes of normalising gendered culturalism, later I will refer to findings of a study in the Netherlands, conducted in 2012. ${ }^{\text {iv }}$ The experiences of my interview partners underline racist dynamics of majority claims of nativism and cultural superiority. 
Majority claims are encompassed by processes of normalisation; a normalisation of culturalized prejudices and anti-Muslim racism intertwined with sexism that predates the recent success of far right parties in various EU Member states.

Yilmaz (2012: 369) points out that there has been a shift in the European political and discursive landscape as 'culture has become central to the questions of belonging and alterity, that is, the ontology of the social has become culturalized'.

The apparently sudden rise of far right populism has to be understood as triggered by a moral panic associated with newly arrived and arriving non-European migrants and refugees since late summer 2015, and a frequency of extremist terrorist attacks in cities such as Paris, Brussels and Istanbul, for example. However, far right and racist perceptions have been growing and being established since the 1990s, and this has to be explored more in-depth in different countries.

As it is argued here, the rise of far right populism is embedded in particular national context of gendered anti-Muslim racism and culturalism that adds to the global phenomenon of Islamophobia (Morgan and Poynting 2013). Here, the research contributes to the exploration of culturalism (Ghorashi 2010), the role of women in the construction of national group boundaries (Yuval-Davis 1997) and everyday racisms (Essed 1991; Essed and Hoving 2014). More specifically the situated context of the Netherlands is used here as a show case for a more general tendency: societal consensus shifted to the acceptance of a far right political rhetoric as well as to gendered anti- Muslim policy interventions, over years There is an emerging literature on individual narratives of Muslim women in the Netherlands, more broadly (see for example, Roggeband and Verloo 2007; Ghorashi 2010; Ghorashi and Vieten 2013; Eijberts 2013). I look, however, at politically active female Moroccan-Dutch minority citizens, who 
experience the normalization of gendered culturalism and anti-Muslim racisms in their daily life, and the way they cope with this.

What is important to acknowledge is that despite a widespread discourse of gendered culturalism and anti-Muslim racism a new generation of female Muslims and 'new' minority citizens challenge gender stereotypes, which are associated with the 'Muslim woman' and her victimhood in the Netherlands. $^{v}$

First, I will review briefly the place of gender and the role of women in debates, and in far right wing populist parties, and second, present a critique of processes of normalisation and clarify the term 'culturalism', the latter projecting a static and homogenous view of cultural difference on Muslims. The conceptual discussion is relevant as it stresses how the same processes of normalisation affect minorities distinctively, and what 'normalisation' of far right everyday anti-Muslim racism does to minority women. To illustrate this multi-faced process I will bring in some of the female voices I interviewed in a comparative study on 'new citizens' inclusion' in three different European countries. The empirical findings illustrate how far right populist perspectives and prejudices entered their daily lives and which counter strategies, the women use to resist intimidations.

\section{Gender and populism}

Gender has a particular role to play in the current far right populist discourses as the gender division understood as ascribed masculine or female sex character shape societies with respect to the way private, semi-private/ semi-public, and finally, public space, is open to individual participation of and performances for women and men. According to Valentine ET. al. (2014: 402), '[s]exism and gender hate as forms of discrimination and prejudice appear to have largely dropped off the geographical map.' 
Despite recurring academic and feminist engagement with institutionalised, or everyday sexism $^{\mathrm{vi}}$ in the public sphere (see for example, McDowall 1983; Fraser 1990; Young 2000; Susen 2011) and ongoing gendered violence in the domestic sphere ${ }^{\mathrm{vii}}$, a bourgeoning far right populist narrative attempts to convince majority voters in different national societies that gendered violence and discrimination of women can be tackled, and, finally, brought down in the public sphere by penalising non-white, non-native, non-Christian men. The international public outcry initiated by what appeared to be systematic sexual attacks and theft offenses by a number of visibly different, minority men on New Year's Eve in some European cities, also triggered contestation about feminist responses to it, and the need to think sexism and racism as intersecting social structures of oppression. viii According to Young (1994: 734) 'Many women regard their womaness (sic!) as an accidental or contingent aspect of their lives and conceive other social group relations - ethnic or national relations, for example - as more important in defining their identity.' This speaks to overlapping angles of different identifications and layers of group belonging with respect to female identities. But nonetheless, as she further argues (1994: 737), women are confronted with 'a set of structural constraints and relations to practico-inert objects that condition action and its meanings.' Following these structural considerations the challenge for critical feminist interventions in current debates is to analyse the tension of far right populism and gender, in particular when speaking of 'emancipatory' rights of woman. As argued above, 'woman' in a national(ist) context is regarded as the 'native' woman, and discursively constructed in opposition to the 'non-native' migrant woman. Mudde $(2004,2013)^{\text {ix }}$, argues that 'nativism' is one of the core elements of far right populism. This nativism could be regarded as an ideology that constructs an overlap between territory (space) and inhabitants (nation) claiming exclusivity for the native group (e.g. imagined as homogenous- autochthon). Wodak (2013) highlights that this 
nativist ideology and an exclusionary chauvinism characterise most prominently far right populism.

The terminology of a so called 'nativism' has been criticised by Yuval-Davis (2011) arguing that 'autochthony' might be a better fit to a 'racist discourse which uses origin, culture and religion as signifiers of immutable boundaries like other forms of racism' ${ }^{\mathrm{x}}$, however, focusing on the 'spatial/territorial' (ibid). Though the differentiation of 'indigeneity' and 'autochthony' is important, the latter being the more problematic discourse of 'privileged hegemonic majorities defending access and resources' (Yuval-Davis 2011, ibid), 'autochthony' similarly does have limits in explaining the core of what 'nativism'entitlement means to contemporary far right populism. An important reference point of claiming that the 'we-I', was 'here' before 'the Other-stranger-them', adds to the established rhetoric of local and national territory ownership, a new dimension of culturalised and Europeanised notions of belonging: a cultural-liberal European cosmopolitanism and a mainstreamed liberal gender discourse encompassing it. This culturist Europeanism adds a new layer to what is regarded as far right populist racism and why 'gendered culturalism' has become the populist racist focus in Europe. Thus, the claim of being 'nativist European' goes beyond the local and a nationalistic anchoring, and mystifies Christian cultural heritage, at large. That said, contemporary far right populism subscribes to supra-national aspects of 'European cultural belonging' as a 'liberal' culturalism agenda; paired with a 'crusade' against Islam. Notably, and as De Lange and Mügge (2015: 63) argue 'Since the mid-1990s, anti-Islam positions have been gradually linked to gender and family. As part of this development, anti-immigrant politics has not only become focused on Muslim immigrants, but has become explicitly gendered.' Whereas Wodak (2013: 28) remarks that in most far right groups 'a hierarchical structure with (male) leaders' is prevalent, timely new studies suggests that female leadership, is catching up (Spierings et El. 2015; Meret 2015; Akkerman 
et El. 2015 Far Right female leaders appeal to the populist demand to regard women foremost in the role of carers, nurtures and - ultimately - mothers. Having said that, in a late modern reading of secular Christian societies, it seems that being divorced (e.g. Marine Le Pen) does not contradict this image. Akkerman (2015: 38) identifies, 'The promotion of the family as a core institution of society, the traditional role of women within the family, opposition to same-sex marriage and to abortion are characteristic elements of conservative agendas. Populist radical right parties support such an agenda, but there are substantial differences between parties.'

These distinctions apply to the subject of family and sexuality, read the latter as 'homosexuality': the Dutch PVV (Partij Voor de Vrijheid) 'has been notable for its defence of women's equality and same-sex partnerships' (Akkerman 2015: 39). Therefore, and illustrated in the case study later, the Dutch context is particularly interesting as a liberal discourse of women's emancipation and a racist anti- Muslim agenda seem to coexist, both shaping the political debate in the public sphere for some years. (For details see Akkerman and Hagelund 2007 ${ }^{\mathrm{xi}}$; De Lange and Mügge 2015)

To summarize, anti-Muslim rhetoric appears as twined with a twisted 'pseudoemancipatory' (Wodak 2013: 28) gender discourse. Betz (2013: 73) acknowledges, too, that the Swiss campaign against minarets, also adopted a 'defence of women's rights' (ibid) rhetoric to make a case that Islam, and gender segregating mosques might be here regarded as a male dominant Muslim space, which 'is sanctioning the subordination of and discrimination of women' (ibid). What is striking is the broad ideological attempt to 'normalize' far right politics. Meret (2015: 100) emphasizes that 'Mother of three, Marine Le Pen managed, as the new FN president, to launch a comprehensive plan of so-called "de-demonization" that 
attempted to "normalize" the party from within, and transform it into a "catch-all protest party"”.

Hence, it needs further exploration how 'normalisation' is depicted, and - in consequence - how we can understand processes of normalisation of far right populism, gendered culturalism and its anti-Muslim racism. As the focus of this paper is on the Netherlands, in the following the dynamics of gendered culturalism are explained and applied to the Dutch context. Gendered culturalism is regarded here as a distinct form of racism introducing a more 'subtler form of excluding immigrant groups than downright racist discourse' (Van den Berg and Schinkel 2009: 406). Further it links to European archives of racisms as 'European history of racisms' (Vieten 2011) with a specific ethnocentric ${ }^{\mathrm{xii}}$ and orientalist perception of the Other.

\section{Normalising everyday far right discourse: gendered culturalism in the}

\section{Netherlands}

While far right politics, e.g. populism, has gained ground in recent years the process of culturalising difference and projecting Muslims as the 'deviant' Other (Ghorashi 2006; 2010) developed since the 1990s in Europe. According to Stolcke (1995: 4) it is 'cultural fundamentalism' that stretches across Europe creating a rigid boundary between secular (Christian) majorities on the one hand, and religious (Orthodox) Islam minorities on the other. Van den Berg and Schinkel (2009: 395) argue that

[t]he Dutch discourse on minorities, immigration and integration has historically been characterized by three phases: (1) a pluralist phase: (2) a phase which emphasis was placed on structural differences and lower structural status in terms of work and education; and (3) a phase in which cultural differences were 
underlined. The current discourse on gender and minorities can be regarded as a specific branch of culturalist discourse.'

The third phase, dominated by culturalist, or gendered culturalism, became more apparent with the public interventions by opponents of multiculturalism, particularly by Fritz Bolkestein (1991) and Paul Scheffer (2000). Bolkestein delivered his speech at a right wing liberal conference in Luzern, and Scheffer published his dossier in a renowned Dutch newspaper. According to Prins (2002), 'new realism' and the 'freedom to speak out openly' frame the change of public mood in the Netherlands encompassing a societal consensus that 'structural factors took the back seat to cultural factors, and discourse became increasingly culturist.' (Van den Berg and Schinkel, 2009: 397).

This culturalism encompasses mainstream Islamophobic views (Wodak 2013; Wodak and Reisigl 2015), and has turned into a 'normalised' gendered lens to view religious-cultural group differences. That means culturalist gendered projection became 'normalised' in a few years, and turned into a hegemonic lens yet before far right parties gained significant ground in parliaments across Europe. According to Young (2000: 86) hegemony 'refers to how the conceptual and normative framework of the members of a society is deeply influenced by premises and terms that make it difficult to think critically about aspects of their social relations or alternative possibilities of institutionalisation and action'.

Hence, hegemony could be understood in this culturalising Otherness- context, as 'a [new] social imaginary that establishes one single horizon of intelligibility [and] ... normalizes itself as the only possible way of thinking about politics' (Smith, 1994: 36). The new hegemony is not so much about change in attitudes (i.e. more negative attitudes towards Muslim immigrants) but about the articulation of a new antagonism between 'us' and 'them': a value-based rather than interest-based 
antagonism that culturalizes and thereby ontologizes social and political identities in new ways even when the identity categories are not defined by mutually exclusive characteristics. The idea of incompatibility of cultures creates the appearance of cultural sameness vis-a-vis Muslim immigrants' purported cultural values.' (Yilmaz 2015: 39)

Hegemonic discourses of normality and normative values, too, subscribe to an ongoing colonializing habit towards the Other. Conceptually 'culture' conveys notions of 'colonialism' as there is a semantic proximity between both words sharing a word rooting in the Latin expression, 'cultus' (Honold and Simons 2002). The colonial habit and lens towards the Other establishes a hierarchy of norms, power and entitlements that are picked upon in processes of normalisation. Young (2006: 96) defines normalisation as follows: 'I refer to processes that construct experiences and capacities of some social segments into standards against which all are measured and some found wanting or deviant.' While accepting that the majority group retains a 'superior culture', and qua belonging to this majority any individual also does have a more emancipatory outlook on women and sexuality, gendered culturalism is established as a normalised view on the Other, e.g. Mulism. Young's position here is related to her reading of Foucault's terminology and discourse of 'normalisation' (Taylor 2009). My adaption of 'normalisation' though is not only confined to control mechanisms of modernity (e.g. the binary of 'traditional vs. modern/ progressive') but aims to problematize the imposition of a certain way of thinking. If it is linked to 'naturalisation' it creates a certain knowledge that is generalised as true and essentialist. Foregrounding processes and dynamics of normalisation also allows to look at the power struggle between concrete actors, the public space and how the 'abnormal' and the 'normal' is positioned temporarily. (Butler 2008) 
In a comparative study of anti-immigrant parties' programmes in Norway and the Netherlands, Akkerman and Hagelund (2007: 208) pinpointed that 'there is a tension between a neo-liberal programme that emphasizes freedom of choice and the political paternalism inherent in a radical uniculturalist position.' The 'uniculturalist' perspective spells out the renunciation from multi-culturalism to mono-or 'uniculturalism'. The latter conveys the racist features of what has been described earlier as gendered culturalism.

In the final section of this paper, I will take the 'nativist and "liberal" agenda' to an empirical side of investigation, and demonstrate how some politically active minority Muslim women cope individually with gendered culturalised perceptions and illustrate the ways 'day to day' far right populism and gendered culturalism became normalised in the Netherlands. As introduced above the Netherlands is an interesting and important case study as this country has a quite established far right party, the PVV with its leader, Geert Wilders, who is influencing the Dutch political and public debates and policy, since 2006. Crucially, Geert Wilders and the PVV 'supported a minority government led by the liberal Volkspartij voor Vrijheid en Democratie (VDD; People's party for Freedom and Democracy) from 2010 to 2012.' (Lange and Mügge 2015: 68)

\section{Female Muslim citizens in the Netherlands: coping with culturalised gender} stereotypes as everyday racism

The following interview sequences are drawn from my fieldwork in the Netherlands, conducted in 2012. The larger research project looked into the ways minority, 'new' citizens in three EU member states describe their feeling of belonging to the majority native collective, to their minority ethno-national collective and to an expanding and imagined space of European belonging. For the Dutch part, I interviewed 14 political key minority activists (Den Haag, Amsterdam, Rotterdam and Maastricht), from October 2011 to May 2012. The focus was on highly educated and also publically outspoken key political activists, who are 
Dutch citizens with a Moroccan hyphened and migration background. I approached individuals I came across as renowned minority activists (e.g. in newspapers, on TV and on the internet), or through local contacts. In terms of age and class; the women were between 25 and end of 30; and all but one immigrated as a child with their parents to the Netherlands. Ten grew up in a working class environment and realized social upward mobility due to educational choice and individual ambition. All semi-structured interviews were verbatim transcribed; they lasted around 1 and a half hours. ${ }^{\text {xiii }}$

Though it was not the main angle of inquiry all the women I spoke to shared their individual experiences with racist threats and discrimination, some lasting back to their young adult life, but often rather a reflection of the end of 1990s, and 9/11 2001 turn in public perceptions of Muslims. All of my interview partners noticed a rise in far right populist anti-Muslim sentiments on an everyday level underlining what Philomena Essed describes and coined as 'everyday racism' (1991).

The Dutch society similar to other countries has undergone and is undergoing a post-2001 transformation, to a security and a counter-terrorism policy regime ${ }^{\mathrm{xiv}}$ that targets Muslims, e.g. particularly a younger generation of Muslim citizens, as a suspicious faith community. Unlike the early 1990s when multiculturalism shaped conflict and integration debates, since 2001, religion, e.g. Islam, has become the dominant identity marker, either as a chosen, or an ascribed category, when investigating and problematizing group belonging, identity formation and social divisions (Vink 2007; Ghorashi 2007).

Back in 2002, the Dutch and gay academic, Pim Fortuyn, gained prominence in the Netherlands when uttering in an interview that 'Islam is a backward culture' (cited in Ghorashi, 2010: 13). His assassination the same year in Hilversum, marks a turning point to the previous understanding of a largely tolerant ${ }^{\mathrm{xv}}$ and non-violent Dutch society. The 'Pim 
Fortuyn list' can be regarded as the first far right, and Populist Party post-2001, in the contemporary Netherlands. The party was resolved in 2008 though. In 2004, another political murder happened $^{\mathrm{xvi}}$ : The film maker, Theo van Gogh, was killed by a young DutchMoroccan man, who lived in Amsterdam. Though the two murderers had very different religious and cultural backgrounds - the first one was an animal rights activists with a white, non-hyphened, ethnically Dutch background - both murderers and the 'cultural' background of both murders, collapsed into one hegemonic narrative of Moroccan criminality and 'perceived danger posed by the presence of fundamentalist Muslims in the Netherlands' (Buitelaar and Stock 2010: 162).

The post-9/11 and the domestic murders as well as the transformation of what people regarded as 'collective' and 'individual' culture impact strongly on my interview partners' daily life.

One of my Dutch-Moroccan interview partners, Orla, who is an academic, too, grew up in a provincial Dutch town. Only when moving to the city of Amsterdam she fully understood the impact of anti-Islam rhetoric, and that of an atmosphere of general suspicion against Muslims, on her personal life. Looking at the public controversy surrounding Islam and the Dutch society post 2001 she pinpoints:

'We wanted to be part of the dialogue, debates and those kind of things, we also wanted to say our thoughts, but there was no space for that, because they just wanted to hear what they thought...For example, our own community, the Moroccan community has managed one of the hundred percent organisations here in the Netherlands, it is called Samenwerkingsorgaan voor Marokkanen ${ }^{x v i i} \ldots$ When they invited people they didn't invite the Moroccan people who also were very 
politically active, but they invited the Dutch who they thought to be much more intelligent or to have more knowledge about the theme.'

Orla characterizes her encounters with majority Dutch people as that of paternalism. Dominant was the feeling of being disregarded and not taken seriously as a political and eloquent voice. The group boundary between ethnical Dutch and hyphened Dutch, particularly Moroccan Dutch, seems to be fixed and encapsulated in a clear hierarchy: Yanow and van der Haar (2013) expose the taxonomy of racialised social categories in the Netherlands, e. g. 'autochtoon' (of Dutch heritage) and 'allochtoon' (of foreign birth). Whereas 'race' is rarely used in public discourse, this taxonomy functions as a surrogate for a similarly racializing subordination of the foreigner as a cultural stranger (ibid). Further, both categories also have been $^{\mathrm{xviii}}$ used in the media, policy and academia since the 1970s and, in consequence, reproduce constantly an imagination of two separate population groups, being grouped according to a lineage of territory and heritage.

Another interview partner, Naomi, who was an elected MP with the party Groenlinks, and living in Amsterdam, too, reflects on the 1990s. She shares her view on the construction of (ethnic) group differences in the Netherlands, predating the later political murders and terrorist attacks.

'I don't really agree with people who say, Holland was such a tolerant country, such a multicultural country. It was a multiethnic country but it was also a segregated country. I still have a lot of white Dutch friends who only know me as a token, a kind of their own unique example of the allochtone gemeenschap in their close by. So it wasn't really multicultural to begin with actually and I think it's more multicultural now than it has ever been since you have these youngsters who are going to the same schools and clubs and talking more to each other. And 
what has happened in the last decade and even longer, is that both peoples in a sense, allochtonen and autochtonen, allochtonen feel a group now as well. If I'm in a group of only white people and there are two Turkish people around, I do feel a link with them, I relate to them, because we have something in common. '

As introduced earlier, the public tone shifted from 'multiculturalism' to a 'clash of cultures' (Van der Berg and Schinkel 2009: 397) in the Netherlands, even before 2001. It is argued here that the racialising terminology of autochthon and allochthon, established in the 1970s and only discredited by the Dutch parliament in March 2016, framed a normalization of essentialist and culturalist group boundaries, for years. Naomi tentatively argues that the bonding between different ethnic-national minorities captures similarities in the positioning and experiences of ethno-religious minorities, visa-vis the hegemonic ethnic Dutch collective. However, she also admits that the mingling of 'different' groups is easier today than it used to be.

Nadine, who works as a consulter and previously as a researcher, also lives in Amsterdam. She describes the legacy of 'culture' and cultural difference as rooted in the ways Dutch society approached the Moroccans, previously.

'In the 70's cultural differences were most important differences. And now cultural difference is important. At first it was a good thing. Cultural differences is something that you have to acknowledge. And now it is if you have a cultural backward position it's your own fault and- so cultural differences are at the forefront again. And now we are 30 years later. And it's, the new buzzword, in critical and public discourse.'

All my interview partners agreed on the outstanding role 'culture' played previously in the context of 'multiculturalism', and the polarizing role it plays now in the Dutch discourse 
of culturalism. Whereas this suggest a continuity in focus on 'culture' as grouping category, we also talked about the shifts in public debates and private encounters triggered by political violence. When I was touching on the political murders that took place in the Netherlands, Orla, for example, confessed that she became witness to the murdered film director, van Gogh.

'I think 9/11, was one of the most ingrijpende gebeurtenissen ${ }^{x i x}$, also for our lives, because we became the Muslims who are dangerous. Another thing is I think the moord op Van $G o g h^{x x}$, because I was there at the time. I was there in the neighbourhood when he was killed, and I have seen him. You have the Dappermarkt, and I was there. And I know that as I saw a lot of politie and people and I went there and I saw een witte deken ${ }^{x x i}$ with I guess the knife still in it. And someone with a bike crossed me and said, you did it again, your kind of people did it again. And I thought, what's happening? Oh my god I don't hope it's a Muslim who killed him.... But I really felt lost at that time. There was no position for us, because now there was really a bedreiging ${ }^{x i i}$, we really are a bedreiging for the Dutch, a danger for the Dutch citizens. So it was very strange to be there, it was also stil $^{x x i i}$, the people didn't speak with each other, they were all thinking.'

Apart from a traumatising experience as, by chance, being that close to the (prominent) victim of a crime, the racialisation of Orla as 'your kind of people did it' appears as typical populist racist perception, threatening not only my interview partner, but turning an individual criminal act into the general responsibility of and blame against all Muslims.

Fatma, another interview partner, who was engaged with a local NGO in Maastricht, felt completely excluded from the overall national and international, mourning of the $9 / 11$ victims. 
'So as if this attack is not mine....as if I couldn't be shocked as equally as you are. I think that is the biggest pain and maybe not even the anti-Islamic attack cause. I was already used to be attacked for being a Moroccan, as a foreigner. I could not claim that this attack was not big for me as it was for you. It was just taken away from me.'

She expresses her deep shock that she was not seen as part of the 'mourning community' but instead addressed as someone close to the ideology of the perpetrators. Otherwise, she rather agreed with Naomi that it was the local and domestic appearance of far right politicians, e. g. Pim Fortuyn, and the experiences that some of her school mates were fond of him, that exposed her more directly to the shifted public discourse in the Netherlands.

'When 9/11 happened, nothing really changed, but then Pim Fortuyn came up. And at that time I didn't watch the news at all. I had no idea what was going on in the Netherlands, in the media. All I knew was what my peer students talked about. For example, I remember at a certain point that there was this whole discussion about some imam and about gays. And you can look it up, they still refer to it, Imam El Moumni and he said something about gays being a disease or whatever, I don't know exactly. I remember feeling very strange, I was like, okay apparently this is something about me, but I'm not sure what you're talking about. I never thought about what I should think about gay people, one of my friends was actually gay, so it was very strange. But then this Pim Fortuyn guy came up and there were some pupils who were very fond of him.'

For Fatma these experiences also motivated her to become more politically engaged.

Looking at the lack of acknowledgement of the deeds of past politics, Naomi judged the current state of discourse in the Netherlands as the absence of dealing with facts: 'We have a fact free 
politics nowadays.' She argued that the turn to far right politics also meant to forget 'the facts' about previous policies:

'Right wing governments, or central right governments, were responsible for family unification. And for other measurements - For example the education in, in the ethnic culture and language was an instrument made possible by the VVD, conservative democrats. So it is all reframed.'

The public arena, among others as represented in democratic institutions such as courts, media and parliament, has become the litmus test of political resilience or resistance towards gendered culturalism, racism and the normalisation of far right populism. Another interview partner challenged the PVV leader, Geert Wilders, in court during the first period of trails against him, 2010-2011: Wilders was accused of intimidating Muslims, and inciting hatred on Dutch Muslims, in 2010 -2011. I asked Amal, about her motivation. She replied with passion:

'You are not regarded as a human being any longer; he uses animal names and terms to address us. For example: 'they breed like rabbits'. This kind of expression does he use. He doesn't talk in an adequate and respectful manner. It doesn't mean that we all have to like each other, but what does it mean if people are addressed as animals and not regarded as human beings? I think this is very awful and I felt deeply insulted. Or take the debate one the 'tax of headscarves', as if the women wearing a scarf don't have a head any longer. And it is not a shawl or cloth, but a rag. And you have to pay the tax, because you are polluting the street, almost like dog shit. Yes, you are compared like this. That's not going to happen, does it? And all of this is discussed seriously in the parliament. ${ }^{\text {xxiv }}$

The 'headscarf- tax' was proposed by Wilders, and discussed in the Dutch parliament. The politisation of the headscarf, and 'the framing of the hijab' (Lettinga 2011) in nationalist policy 
responses, developed along the lines of a mainstreaming of gendered culturalism in different countries, prominently in France, but also in Germany (Fehr 2011), as well as in the Netherlands (Lettinga, ibid). Though only two of my interview partners wore a headscarf actually, Orla and Fatimah, the latter living in Den Haag, all were very upset and felt intimidated. While proposing a 'headscarf-tax', Wilders took the public contestation and the outlawing of the headscarf in some countries to a new level. As an elected MP and, further, acting in support of the minority government in the period 2010 to 2012 , he could raise this in parliament.

In 2011, the Dutch court decided that Wilders was targeting Islam, but not Muslims, and that the right to free speech meant more to the democratic Dutch public space and society than the feelings and perceptions of minority Dutch citizens with Moroccan-Muslim background. In 2016, new criminal proceedings have been initiated trying to stop Wilder's racist speech by trial $^{\mathrm{xxv}}$. Jones (2014: 68) argues that in response to Wilders' 2014 'entitlement racism' (Essed and Hoving, 2014: 14; cited in Jones, ibid) 'more than 5,000 legal complaints, mostly from Dutch citizens of "Moroccan background", were filed.

\section{Conclusion}

This paper has argued that gender and gendered culturalism play a prominent role in the normalisation of far right discourses. Gendered culturalism puts a static 'cultural' marker between a majority and minority group. In effect, a normalised far right discourse emerged over years that culturalizes the position of minority Muslim women against a 'pseudoemancipatory' nativist claim of cultural superiority with respect to majority women (and men) in liberal European societies. The Dutch society is of particular interest here, as the far right party, PVV, and its leader, Geert Wilders, promote a gendered culturalised view on Moroccan- Dutch, for some time. The interview sequences with female Moroccan-Dutch 
citizens illustrate how anti-Muslim racism and gendered culturalism interfere in their private and everyday lives for years. Predating the anti-Muslim discourses post-9/11 2001 and the shock about the two specific political murders (Pim Vortuyn and Theo van Gogh) the binary constructed 'autochthon and allochthon' social categories have been used in academia, media and policy, until recently. The current development to far right populism has to be contextualised against these established racialising discourse.

Despite a majority consensus downplaying the 'normalisation' of gendered anti-Islam racism and gendered culturalism, female Muslim minority citizens balance personal experiences with this institutionalised everyday racism individually, and also engage politically based on their claim to be Dutch, and of 'having a right to have rights' (Arendt 1994).

\section{References}

Arendt, H. (1994). The Origins of Totalitarianism. New York: Harcourt Books.

Akkerman, T. and A. Hagelund (2007). "”Women and children first!” Anti-immigration parties and gender in Norway and the Netherlands'. Patters of Prejudice, 41 (2), 197-214.

Akkerman, T. (2015). 'Gender and the radical right in Western Europe: a comparative analysis of policy agendas'. Patterns of Prejudice, 49 (1-2), 37-60.

Betz, H.-G. (2013). 'Mosques, Minarets, Burqas and Other Essential Threats: The Populist Right's Campaign Against Islam in Western Europe', in: Ruth Wodak, Majid 
Khosravinik and Brigitte Mral (eds.) Right-Wing Populism in Europe - Politics and Discourse, London: Bloomsbury Publishing, 71-87.

Bolkestein, F. (1991) 'On the collapse of the Soviet Union', Address to the Liberal International Conference, Luzern.

Buitelaar, M. and F. Stock (2010). 'Making Homes in Turbulent Times: Moroccan-Dutch Muslims Contesting Dominant Discourses of Belonging'. In: Muslim Diaspora in the WestNegotiating Gender, Home and Belonging. Farnham: Ashgate, 163 - 179.

Butler, J. (2008). 'Sexual Politics, torture, and secular time’, British Journal of Sociology vol. $59(1), 1-23$.

Cooper, D. (2004). Challenging Diversity - Rethinking Equality and the Value of Difference. Cambridge: University of Cambridge Press.

De Koster, W., Achterberg, P. Van der Waal, J. Van Bohemen, S. and R. Kemmers (2014). 'Progressiveness and the New Right: The Electoral Relevance of Culturally Progressive Values in the Netherlands', West European Politics 37 (3), 584-604.

Eijberts, M. (2013). Migrant Women Shout It Out Loud - The Integration/ Participation Strategies and Sense of Home of First-and Second-Generation Women of Moroccan and Turkish Descent. Amsterdam: VU University Press (PhD Thesis)

Enloe, C. (1990). "'Womenandchildren": making feminist sense of the Persian Gulf Crisis', Village Voice, Sept 25.

Essed, Ph. (1991). Understanding Everyday Racism. An Interdisciplinary Theory. London: Sage 
Essed, Ph. and I. Hoving (eds.), (2014) Dutch Racism, Amsterdam/ New York: Rodopi.

Fehr, S. (2011). 'Intersectional Discrimination and the Underlying Assumptions in the French and German Headscarf Debates: An Adequate Legal Response?' in: Dagmar Schiek and Anna Lawson (eds.) European Union Non-Discrimination Law and Intersectionality. Investigating the Triangle of Racial, Gender and Disability Discrimination. Farnham: Ashgate, 111-124.

Fraser, N. (1990). 'Rethinking the Public Sphere: A Contribution to the Critique of Actually Existing Democracy', Social Text (25/26), 56-80.

Ghorashi, H. (2007) 'Who Dares to Experiment with Culture?' in: Citizens and Subjects: the Netherlands, for example. Rosi Bradiotti, Charles Esche and Maria Hlavajova (eds). Zuerich: jrp/ ringier. 125-135.

Ghorashi, H. (2010) ‘Culturalist Approach to Women’s Emancipation in the Netherlands'. In: Haideh Moghissi and Halleh Ghorashi (eds). Muslim Diaspora in the West - Negotiating Gender, Home and Belonging. Farnham: Ashgate, 11-22.

Ghorashi, H. and U. M. Vieten (2013). 'Female Narratives of "New” Citizen's Belonging(s) and Identities in Europe: Case Studies from the Netherland and Britain', Identities: Global Studies in Culture and Power 19 (6), 725-741.

Honold, A. and Simons, O. (eds.), (2002. Kolonialismus und Kultur-Literatur, Medien, Wissenschaft in der deutschen Gründerzeit des Fremden. Tübingen/ Basel: A Francke 242.

Jones, G. (2014). ‘Just Causes, Unruly Social Relations. Universalist-Inclusive Ideals and Dutch Political Realities.' In: Ulrike M Vieten (ed.) Revisiting Iris Marion Young on Normalisation, Inclusion and Democracy. Basingstoke: Palgrave Macmillan, 67-86. 
Kulpa, R. and J. M. Silva (2016). ‘Decolonializing Queer Epistemologies' in: Gavin Brown and Kath Brown (eds.) The Ashgate Research Companion to Geographies of Sex and Sexualities, Farnham: Ashgate, 139-142.

Morgan, G. and S. Poynting (eds.), (2013). Global Islamophobia: Muslims and moral panic in the West. London: Sage.

De Lange, S. L. and L. M. Muegge (2015). 'Gender and right-wing populism in the Low Countries: ideological variations across parties and time'. Patterns of Prejudice 49 (1-2), 6180.

Lettinga, D. N. (2011). Framing the Hijab. The governance of intersecting religious, ethnic and gender differences in France, the Netherlands and Germany, Amsterdam: VU Amsterdam, PhD Thesis.

Lugones, M. (2007). 'Heterosexualism and the Colonial/modern Gender System, Hypathia 22 (1): 198-219.

McDowell, L. (1983). 'Towards and Understanding of the Gender Division of Urban Space.' Environment and Planning D: Society and Space 1: 59-72.

Meret, S. (2015). 'Charismatic female Leadership and gender: Pia Kjærsgaard and the Danish People's Party', Patterns of Prejudice, 49 (1-2), 81-102.

Prins, B. (2002) 'The nerve to break Taboos: New Realism in the Dutch discourse on Multiculturalism.' Journal of International Migration and Integration vol. 3 (3-4), 363-379.

Puar, J. K. (2007) Terrorist Assemblages: Homonationalism in Queer Times. Durham: Duke University Press. 
Roggeband, C. and M. Verloo (2007). 'Dutch Women are Liberated, Migrant Women are a Problem: The Evolution of Policy Frames on Gender and Migration in the Netherlands, 1995-2005'. Social Policy \& Administration vol. 41, no. 3, 271-288.

Scheffer, P. (2000) 'Het Multiculturele drama', NRC Handelsblad, 29.1.2000; http://retro.nrc.nl/W2/Lab/Multicultureel/scheffer.html; checked 25.7.2016Spierings, N., Zaslove, A., Mügge, L. M. \& S. L. De Lange (2015), Gender and populist radical-right politics: an introduction', Patterns of Prejudice, 49 (1-2), 3-15.

Spierings, N. and A. Zaslove (2015). 'Conclusion: dividing the populist radical right between "liberal nativism" and traditional concepts of gender', Patterns of Prejudice, 49 (12), 163-173.

Stolcke, V. (1995). 'Talking Culture: New Boundaries, New Rhetorics of Exclusion in Europe', Current Anthropology vol. 36 (1), 1-24.

Susen, S. (2011). 'Critical Notes on Habermas' Theory of the Public Sphere, Sociological Analysis 5(1), 37-62.

Taylor, D. (2009). 'Normativity and Normalisation', Foucault Studies No. 7, 45-63.

Valentine, G. (1993). '(Hetero)sexing Space: Lesbians Perceptions and Experiences of Everyday Spaces', Environment \& Planning D: Society \& Space 11: 395-413.

Valentine, G., Jackson, L. \& L. Mayblin (2014). 'Ways of seeing: sexism the forgotten prejudice? Gender, Place and Culture 21 (4): 401-414. 
Van den Berg, M. and W. Schinkel (2009) "'Women from the catacombs of the city': gender notions in Dutch culturist discourse'. Innovation: The European Journal of Social Science Research 22 (4), $393-410$.

Vieten, U. M. (2011). The conceptual order of multiple discrimination: situating difficult genealogies of race and ethnicity' (2011) in: D. Schiek and A. Lawson (eds.) EU Non-Discrimination Law and Intersectionality - Investigating the triangle between racial, gender and disability discrimination, Farnham: Ashgate, 63-76.

Vieten, U. M. (2012). Gender and Cosmopolitanism in Europe: A Feminist Perspective. Farnham: Ashgate.

Vieten, U. M. (2014), ed. Revisiting Iris Marion Young on Normalisation, Inclusion ion and Democracy. London: Palgrave Macmillan.

Vieten, U. M. (2016) 'Notions of conflict and "new" citizen's inclusion: post-cosmopolitan contestations in Germany', in: U. M Vieten \& G. Valentine (eds.) Cartographies of Differences - international perspectives on living with difference, Bern: Peter Lang publisher, 109-133.

Vink, M. P. (2007). 'Dutch “Multiculturalism” Beyond the Pillarisation Myth', Political Studies Review vol. 5, 337-350.

Wodak, R. (2013). “”Anything Goes!” - The Haiderization of Europe' in: Ruth Wodak, Majid KhosraviNik and Brigitte Mral (eds.) Right-Wing Populism in Europe - Politics and Discourse, London: Bloomsbury Publishing, 23-37. 
Wodak, R. and M. Reisigl (2015). 'Discourse and Racism', in: Deborah. Tannen, H. E: Hamilton and Deborah Schiffrin (eds.) The Handbook of Discourse Analysis. Chichester: Blackwell, 576-596.

Yanow, D. and M. van der Haar (2013). 'People out of place: allochthony and autochthony in the Netherlands' identity discourse - metaphors and categories in action', Journal of International Relations and Development Number 16, 227-261.

Yilmaz, F. (2012). 'Right-Wing Hegemony and Immigration: How the Populist Far Right Achieved Hegemony through the Immigration Debate in Europe', Current Sociology, 60 (3), 368-381.

Yilmaz, F. (2015). 'From immigrant worker to Muslim immigrant: Challenges for Feminism', European Journal of Women's Studies, vol. 22 (1), 37-52.

Young, I. M. (1994). 'Gender as seriality: thinking about women as social collective', Signs, vol. 19 (3), 713-738.

Young, I. M. (2000). Inclusion and Democracy. Oxford: Oxford University Press.

Young, I. M. (2006). 'Responsibility and Global Justice: a social connection model', Social Philosophy and Policy 23 (1), 102-130.

Yuval-Davis, N. (1997) Gender and Nation. London: Sage.

Yuval-Davis, N. (2011) 'The dark side of democracy: autochthony and the radical right', Open democracy, 26.7.2011; https://www.opendemocracy.net/5050/nira-yuval-davis/darkside-of-democracy-autochthony-and-radical-right, checked 25.7.2016. 


\begin{abstract}
i (http://www.spiegel.de/international/germany/cologne-attacks-trigger-raw-debate-on-immigration-ingermany-a-1071175.html)

ii (http://councilforeuropeanstudies.org/critcom/the-rise-of-the-extreme-right-in-europe-the-gender-andsexuality-dimensions-of-anti-immigrant-discourse/

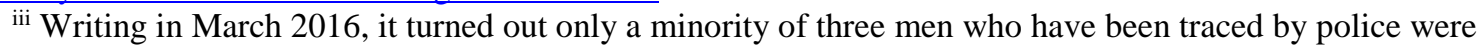
refugees, however the majority of attackers been of Moroccan, Tunisian and Algerian background.

http://www.independent.co.uk/news/world/europe/cologne-only-three-out-of-58-men-arrested-in-connectionwith-mass-sex-attack-on-new-years-eve-are-a6874201.html.

iv This country study was part of an international and comparative research project (2010-2012) looking at nodes of social complexity and inclusion of 'new' citizens in Britain, Germany and the Netherlands. The project was funded by the VSB.

${ }^{\mathrm{v}}$ I am referring here only to the Netherlands. Due to the limits of words and space I am not able to elaborate on Britain or Germany. See, for example Vieten, U. M. (2016).

${ }^{\mathrm{vi}}$ http://everydaysexism.com/

vii According to the European Network Against Racism (2016), citing the FRA dignity report, 'more than $30 \%$ of all women in the EU reported experiencing sexual or physical violence in their life time, mostly from a family member or intimate partner.' (2016:11)

viii http://whttp://www.spiegel.de/international/germany/german-feminists-debate-cologne-attacks-a$\underline{1072806 . h t m l w w}$

${ }^{\mathrm{ix}}$ https://www.opendemocracy.net/can-europe-make-it/cas-mudde/populism-in-europe-primer right

${ }^{x}$ https://www.opendemocracy.net/5050/nira-yuval-davis/dark-side-of-democracy-autochthony-and-radical-

${ }^{x i}$ In 2007, Akkerman and Hagelund stated in their conclusion, 'that the radical right has certainly not become mainstream, some space for the left and the right to act in common sense to have opened up in the often polarized field of immigration politics' (2007: 214). Nearly ten years later, this looks different though.

xii De Koster et al. (2014: 597) analysed the relevance of apparently 'cultural progressive' views in voting for fra right parties in the Netherlands, and found that overall, 'new-rightist voting proves strongly driven by ethnocentrism.'

xiii Most interviews had been conducted in English, but on three occasions my interview partner preferred to talk to me while answering my questions in Dutch. I posed the questions in English though.
\end{abstract}

${ }^{\text {xiv }}$ https://www.government.nl/latest/news/2011/04/20/national-2011-2015-counterterrorism-strategy-hasbeen-presented

${ }^{x v}$ We will learn later that this perception of a genuinely 'tolerant' society narrative is not shared, automatically.

http://www.tariqmodood.com/uploads/1/2/3/9/12392325/from_multiculturalism_to_multifaithism.pdf;

${ }_{\text {xvii }}$ A Cooperation body for Moroccans

xviii I learned that the Dutch parliament (with a slight majority) decided in March 2016 to review this binary terminology, e. g. arguing to abandon it.

${ }^{x i x}$ Radical events or far-reaching incidents.

${ }^{x x}$ The murder of van Gogh.

${ }^{x x i}$ A white blanket.

xxii 'Threat'.

xxiii 'Quiet'.

xxiv Je bent geen mens meer, het zijn ook allemaal dierlijke termen die hij gebruikt. "Ze planten zich voort als konijnen", allemaal van dat soort dingen, hij kan niet eens meer op een menselijke manier over je spreken. We hoeven niet allemaal met z'n allen door één deur te kunnen of elkaar aardig te vinden, maar waar begint het als je mensen niet meer ziet als mens maar als de laagste diersoort. Dat vind ik toch wel heel erg, dat raakt me best wel diep. Net zoals dat 'kopvoddentax', dus al die vrouwen die een hoofddoek dragen hebben geen hoofd maar een kop. En het is geen doek of een sjaal maar een vod. En daarover betaal je belasting want je vervuilt de straat, net zoals we hondenpoep hebben. Dus je wordt vergeleken. Dat kan toch niet? In het parlement.

${ }^{x x v}$ http://www.theguardian.com/world/2016/mar/18/dutch-far-right-leader-geert-wilders-goeson-trial-forinciting-hatred

7975 words 